\title{
Studies on Survey of Fusarium wilt of Pea (Pisum sativum L.) and its Management by Native Trichoderma Isolates and Commercial Trichoderma under Pot Condition in Manipur
}

\author{
Kripalini N. ${ }^{1 *}$, Mohan Kumar Biswas ${ }^{1}$, Ph. Sobita Devi² and Bireshwar Sinha²
}

${ }^{1}$ Dept. of Plant Protection, Palli-Siksha Bhavana, Visva Bharati, Sriniketan West Bengal (731 236), India

${ }^{2}$ Dept. of Plant Pathology, College of Agriculture, CAU, Iroisemba, Imphal (795 005), India

\section{Corresponding Author}

Kripalini N.

e-mail: bibiningom44@gmail.com

\author{
Article History \\ Article ID: AR1927 \\ Received in 09 ${ }^{\text {th }}$ November, 2018 \\ Received in revised form $31^{\text {st }}$ December, 2018 \\ Accepted in final form 09 ${ }^{\text {th }}$ January, 2019
}

\begin{abstract}
A detailed survey was conducted for disease incidence of pea wilt at seven pea growing districts of Manipur viz., Imphal East, Imphal West, Thoubal, Senapati, Ukhrul, Tamenglong and Bishnupur during 2014-2015. The highest disease incidence was found in Litan of Ukhrul district (39.50\%) and lowest was found at Toubul of Bishnupur district (10.70\%). Under pot experiment, efficacy of four native Trichoderma isolates i.e., TIE-1 TBI-2, TIW-1, TSE-1 and two commercial Trichodema spp. viz T. viride and T. hamatum of seed, soil and seed plus soil treatment against wilt of pea showed reduction in disease incidence. Among the different treatments seed+soil treatment was found better than the soil and seed treatment alone. The highest germination percentage was observed in isolate TIE-1 of seed (60\%), soil $(66.60 \%)$ and seed+soil treatment $(80.20 \%)$ and lowest germination percentage was observed in commercial T. hamatum of seed $(53.60 \%)$, soil $(60.00 \%)$ and seed+soil treatment $(65.00 \%)$. Disease incidence of four native Trichoderma isolates and two commercial Trichoderma were found nil in 30 DAS. In 60 DAS the highest disease incidence was found in commercial T. hamatum in seed treatment $(20.00 \%)$ and lowest disease incidence was found in native Trichoderma TSE-1 of seed+soil treatment (2.50\%) whereas in 90 DAS highest disease incidence was also found in T. hamatum in soil treatment (40.00\%) and lowest disease incidence was found in native Trichoderma isolate TIE-1 of seed+soil treatment (10.66\%). The highest plant height was recorded in seed+soil treatment of isolate TBI-2 (70.28 cm at 90 DAS). However in seed+soil treatment of Trichoderma isolate TIE-1 recorded the highest plant canopy (2085.03 $\mathrm{cm}^{2}$ at 90 DAS) no. of pods plant ${ }^{-1}(5.34)$ and yield $\left(6.91 \mathrm{~g} \mathrm{pot}^{-1}\right)$.
\end{abstract}

Keywords: Survey, Fusarium, native, Trichoderma, isolates

\section{Introduction}

Pea (Pisum sativum L.) is an important cool season pulse crop and widely cultivated throughout the world. It is native of South Europe and grown a garden or field crop throughout the temperate regions of the world and was originally cultivated in the mediterranean basin (Smartt, 1990; Sardana et al., 2007). In Manipur field pea is one of the most important pulse crops grown in 26,000 ha area occupying about $85 \%$ of the total pulses area (Anonymous, 2015). The average national productivity of field pea is $911 \mathrm{~kg}^{-1}$ (Anonymous, 2013). It is attacked by several disease caused by fungi, bacteria and viruses. Among these diseases, wilt of pea caused by Fusarium oxysporum f.sp. pisi is one of the most destructive disease and occur as an epiphyte almost every year. (Phal and Choudhary, 1983; Sharma et al., 1989; Haglund and Kraft, 2001). Pea wilt caused by Fusarium oxysporum f.sp.pisi has been reported wherever peas are grown commercially (Kraft and Peleger 2001) Fusarium wilt of pea was first recognized during 1918 by Bisby in Minnesota (Chupps and Sherf, 1960). In India, it was first reported by Sukapure et al., 1957. The pathogen is soil-borne fungus, surviving from year to year in the soil as thick-walled chlamydospores, that can sit in the soil surviving all kinds of conditions for more than 10 years (11 Kraft, 1995). Fusarium oxysporum penetrates pea roots and infects the vascular system at any growth stage (Infantino et al., 2006)

Modern agriculture is very much dependent on the use of chemical pesticides to control plant pathogens in which the repeated use of such chemicals increased resistance among the target organisms. Therefore, management of plant pathogens by using biocontrol agents has been considered as a potential control strategy in recent years. Trichoderma $\mathrm{sp}$. is one of the most important biocontrol agent used for management of different diseases (Harman, 2004). Trichoderma spp. are free living fungi that are common in soil and root ecosystems and promote plant growth (Yedidia, I and Chet, I. (2001). Trichoderma spp. are effective in control of 
soil/seed-borne fungal diseases in several crop plants (Kubicek et al., 2001). Trichoderma spp. can directly impact other fungi, after sensing a suitable fungal host, Trichoderma sp. responds with the production of antibiotic compounds, formation of specialized structures, and degradation of the host's cell wall, followed by the assimilation of its cellular content, a process known as mycoparasitism (Chet and Chernin, 2002; Steyaert et al., 2003; Benitez et al., 2004). The mechanisms of mycoparasitism, antibiosis and competition afforded by Trichoderma spp. have been widely studied (Howell, 2003; Harman et al., 2004b).

Due to the presence of rich biodiversity in the Indo-Burma Biodiversity hot spot region, Manipur is likely to harbor useful Trichoderma isolates. During recent years, wilt of pea has become very serious in many pea growing areas of Manipur. So far, not much research has been done on the use of native microbial agents for the management of Fusarium wilt of pea disease in this region. Therefore, the present study will be undertaken with an aim to minimize the wilt disease with an eco-friendly manner with the following objectives; Survey of the natural occurrence of wilt of pea caused by Fusarium oxysporum f. sp. pisi in differrent districts of Manipur and its management by native Trichoderma isolates and commercial Trichoderma under pot condition.

\section{Materials and Methods}

\subsection{Disease survey}

Survey on Fusarium wilt of pea was conducted in different pea growing districts of Manipur i.e.Imphal West, Imphal East, Bishnupur, Thoubal, Tamenglong and Ukhrul Districts during the year 2014 and 2015. In each place, four fields of more or less uniform size were selected at random. Disease incidence was recorded by random sampling and diseased samples were collected separately for in vitro study. Percentage of disease incidence was calculated by following formula:

Percentage of disease incidence will be calculated by following formula:

Per cent disease incidence $=\frac{\text { No. of diseased plants }}{\text { Total numbers of plants }} \times 100$

2.2. Collection of the disease samples and isolation of causal pathogen

Diseased plants were collected from the field of different districts of Manipur and the diseased samples were cut into small pieces of 2-3 $\mathrm{mm}$ size. These pieces were surface sterilized with $1 \%$ sodium hypochlorite solution for 2-3 minutes and then rinsed with distilled water. The sterilized pieces were then inoculated on PDA slants. The inoculated slants were incubated at $28 \pm 1{ }^{\circ} \mathrm{C}$ for 7 days. After 7 days the fungal isolates appearing on the stem or root pieces were identified and transferred to PDA for purification.

Identification of the causal fungus and pathogenicity test were carried out in the Department of Plant Pathology, College of Agriculture, CAU, Imphal, India. Culture was maintained on freshly prepared PDA slants inside the refrigerator and periodically sub cultured to fresh medium during the investigation.

\subsection{Pathogenicity test}

Pathogenicity test of the isolated fungus was conducted. Soil inoculation with pathogen was done by means of rice seed inoculums technique of Weideman and Wehner (1993). Five $5 \mathrm{~mm}$ diameter discs cut from the actively growing edge of Fusarium oxysporum f.sp. pisi. Colony on PDA was used to inoculate $50 \mathrm{~g}$ of rice seeds. Rice seeds was dipped in water for 48 hours and autoclaved at $121^{\circ} \mathrm{C}$ for $15-20$ minutes for two consecutive days prior to inoculation. The inoculated rice seeds was incubated for 21 days at $28 \pm 1^{\circ} \mathrm{C}$ and then used for soil inoculation. Soil was sterilized in autoclave at $121^{\circ} \mathrm{C}$ for two hours for two consecutive days. Soil inoculation was done by mixing $20 \mathrm{~g}$ of the inoculated rice seed with $1 \mathrm{~kg}$ soil. Seeds without inoculum served as control. Four seeds of pea were sown pot $^{-1}$ and ten pots were kept for each treatment until symptoms developed. Fungus from artificially induced disease plants showing wilt symptoms was re isolated to confirm the pathogenicity of the causal fungus in vitro.

\subsection{Collection of soil sample from rhizosphere of Pea}

The soil samples were collected from the rhizosphere of pea at different pea growing districts of Manipur i.e.Imphal West, Imphal East, Bishnupur, Thoubal, Tamenglong and Ukhrul Districts of Manipur. Soils was taken from the rhizosphere of healthy pea plants from the depth ranging between $5-6 \mathrm{~cm}$ depth soil by removing top $2 \mathrm{~cm}$ surface soil. The soil was air dried under shade and kept sealed in cloth bag into refrigerator at $4{ }^{\circ} \mathrm{C}$ for subsequent use until needed. Five soil samples were randomly collected from each location.

\subsection{Isolation of the antagonists}

Trichoderma were isolated from different areas by soil dilution plate technique (Dhingra and Sinclair, 1995) using Trichoderma specific medium (TSM) (Elad and Chet, 1983) modified by Saha and Pan (1997). From each sample, $10 \mathrm{~g}$ of soil was added to $90 \mathrm{ml}$ of distilled water and vigorously shaken using a shaker for 20-30 minutes. From this, three fold serial dilutions were made by pipeting $10 \mathrm{ml}$ into additional dilution water. From the final dilution $\left(10^{-3}\right)$, aliquots of $1 \mathrm{ml}$ each were spread on $9 \mathrm{~cm}$ diameter plates, containing TSM and incubated at $28 \pm 1{ }^{\circ} \mathrm{C}$ for 7 days. All the identified species of Trichoderma were maintained in PDA slants inside the refrigerator at $4{ }^{\circ} \mathrm{C}$ for subsequent uses.

\subsection{Mass production of pathogens}

The pathogen, F. oxysporum was multiplied by growing in rice seed by following the method of Weideman and Wehner (1993). Rice seeds were dipped in water for 48 hours and autoclaved at $121{ }^{\circ} \mathrm{C}$ for $15-20$ minutes for two consecutive days. The mycelial disc ( $5 \mathrm{~mm}$ diameter) of $F$. oxysporum was picked up from young growing culture and was inoculated into 
$20 \mathrm{~g}$ sterilized rice seed inside polypropylene bag. The mouth of polypropylene bags were sealed with cotton plug duly tied with fine but stiff thread and was incubated at $28 \pm 1^{\circ} \mathrm{C}$ for 21 days inside BOD incubator with periodical shaking to avoid formation of clump. When the medium fully cover with test fungus, which was immediately used to transfer into pots by inoculation of test pathogens for pot experiment.

\subsection{Mass production of Trichoderma isolates}

The selected isolates of Trichoderma were mass multiplied in rice bran+mustard cake substrate following the methods (Pan and Bhagat, 2007). The rice bran+mustard cake at the rate 1:1 ratio ( $\mathrm{w} \mathrm{w}^{-1}$ ) was mixed thoroughly and filled into the double layered polypropylene bags, plugged with cotton plug and tied with fine thread and finally sterilized at $121^{\circ} \mathrm{C}$ for $30 \mathrm{~min}$ for two consecutive days. The mycelial suspension $\left(1 \times 10^{5} \mathrm{ml}^{-1}\right.$ conidia) was inoculated into polypropylene bags containing rice bran+mustard and incubated at $28 \pm 1{ }^{\circ} \mathrm{C}$ for 21-25 days with periodical shaking to avoid formation of clump and uniform growth and sporulation of Trichoderma in the said medium. The appearance of green colouration throughout polypropylene bag was indicative of matured culture of Trichoderma and was used immediately in pot experiment against Fusarium oxysporum $f$. sp. pisi

\subsection{Pot experiment}

Four native Trichoderma isolates was evaluated along with two commercial Trichoderma spp. viz., $T$. viridae and $T$. hamatum against Fusarium oxysporum f. sp. pisi. under pot condition following seed priming and soil treatment. The untreated pots were served as control. Pot trails were taken in Randomized block design (RBD) with three replications. The mycelial and conidial forms of inoculums were prepared. Pea seeds are thoroughly washed with distilled water, air dried and finally dipped into the suspension of bioagents for few minutes, stirred thoroughly to ensure uniform coverage of seeds with suspension of bioagents. The details of treatments are given in the Table 1.

In all the treatments, observations on germination \%, disease incidence were recorded at 30,60 and 60 days after planting. Plant height and plant canopy at 30,60 and 90 days after planting were also measured with the help of scale. Five plants were selected from each replication for each treatment. The numbers of pods plant ${ }^{-1}$ of each five selected plants were counted and averages were calculated. Pods of pea were harvested and yield of pods of each pot were taken.

\section{Results and Discussion}

\subsection{Disease survey}

A detail survey was conducted for disease incidence of pea wilt in different pea growing districts of Manipur. Field survey was conducted at seven different districts of Manipur viz., Imphal East , Imphal West, Thoubal, Senapati. Ukhrul, Tamenglong and Bishnupur during 2015 and 2016 (Table 2). Results indicated that highest disease incidence was found
Table 1: Details of treatments for management of Fusarium wilt of pea under pot condition

\begin{tabular}{|c|c|}
\hline Treatments & Treatments details \\
\hline $\mathrm{T}_{1}$ & $\begin{array}{l}\text { Biopriming of seed with Trichoderma isolate } \\
(\mathrm{TIE}-1) @ 5 \mathrm{~g}\left(1 \times 10^{8} \mathrm{cfu}^{-1}\right) \mathrm{kg}^{-1} \text { seed }\end{array}$ \\
\hline$T_{2}$ & $\begin{array}{l}\text { Soil treatment with Trichoderma isolate } \\
\text { (TIE-1) @ } 25 \mathrm{~g} \text { rice bran }\left(1 \times 10^{8} \mathrm{cfu} \mathrm{g}^{-1}\right) \mathrm{plot}^{-1}\end{array}$ \\
\hline $\mathrm{T}_{3}$ & $\mathrm{~T}_{1}+\mathrm{T}_{2}$ \\
\hline $\mathrm{T}_{4}$ & $\begin{array}{l}\text { Biopriming of seed with Trichoderma isolate } \\
\text { (TBI-2) @ } 5 \mathrm{~g}\left(1 \times 10^{8} \mathrm{cfu} \mathrm{g}^{-1}\right) \mathrm{kg}^{-1} \text { seed }\end{array}$ \\
\hline $\mathrm{T}_{5}$ & $\begin{array}{l}\text { Soil treatment with Trichoderma isolate (TBI- } \\
\text { 2) @ } 25 \mathrm{~g} \text { rice bran }\left(1 \times 10^{8} \mathrm{cfu} \mathrm{g}^{-1}\right) \text { plot }^{-1}\end{array}$ \\
\hline $\mathrm{T}_{6}$ & $\mathrm{~T}_{4}+\mathrm{T}_{5}$ \\
\hline $\mathrm{T}_{7}$ & $\begin{array}{l}\text { Biopriming of seed with Trichoderma isolates } \\
\text { (TIW-1)@ } 5 \mathrm{~g}\left(1 \times 10^{8} \mathrm{cfu} \mathrm{g}^{-1}\right) \mathrm{kg}^{-1} \text { seed }\end{array}$ \\
\hline $\mathrm{T}_{8}$ & $\begin{array}{l}\text { Soil treatment with Trichoderma isolates } \\
\text { (TIW-1)@ } 25 \mathrm{~g} \text { rice bran }\left(1 \times 10^{8} \mathrm{cfu} \mathrm{g}^{-1}\right) \text { plot }^{-1}\end{array}$ \\
\hline $\mathrm{T}_{9}$ & $\mathrm{~T}_{7}+\mathrm{T}_{8}$ \\
\hline $\mathrm{T}_{10}$ & $\begin{array}{l}\text { Biopriming of seed with Trichoderma isolates } \\
\text { (TSE-1) @ } 5 \mathrm{~g}\left(1 \times 10^{8} \mathrm{cfu} \mathrm{g}^{-1}\right) \mathrm{kg}^{-1} \text { seed }\end{array}$ \\
\hline $\mathrm{T}_{11}$ & $\begin{array}{l}\text { Soil treatment with Trichoderma isolates } \\
\text { (TSE-1) @ } 25 \mathrm{~g} \text { rice bran }\left(1 \times 108 \mathrm{cfu} \mathrm{g}^{-1}\right) \text { plot }^{-1}\end{array}$ \\
\hline $\mathrm{T}_{12}$ & $\mathrm{~T}_{10}+\mathrm{T}_{11}$ \\
\hline $\mathrm{T}_{13}$ & $\begin{array}{l}\text { Biopriming of seed with commercial } \\
\text { Trichoderma viridae@ } 10 \mathrm{~g} \mathrm{~kg}^{-1} \text { seed }\end{array}$ \\
\hline $\mathrm{T}_{14}$ & $\begin{array}{l}\text { Soil treatment with commercial Trichoderma } \\
\text { viridae@ } 100{\mathrm{~g} 10 \mathrm{~kg}^{-1} \text { organic manure }}\end{array}$ \\
\hline $\mathrm{T}_{15}$ & $\mathrm{~T}_{13}+\mathrm{T}_{14}$ \\
\hline $\mathrm{T}_{16}$ & $\begin{array}{l}\text { Biopriming of seed with commercial } \\
\text { Trichoderma hamatum @ } 10 \mathrm{~g}^{1 \mathrm{~kg}^{-1} \text { seed }}\end{array}$ \\
\hline $\mathrm{T}_{17}$ & 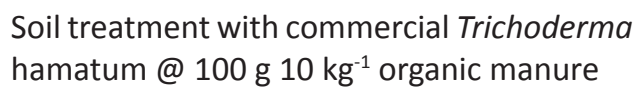 \\
\hline $\mathrm{T}_{18}$ & $T_{16}+T_{17}$ \\
\hline $\mathrm{T}_{19}$ & Control (without Trichoderma treatment) \\
\hline
\end{tabular}

in Litan of Ukhrul (39.50\%), followed by Kashung khullen of Ukhrul (33.30\%), Thongju of Imphal East (30.80\%), Lilong of Thoubal (26.90\%), Awangkhul of Tamenglong (26.00\%) , Mao Maram of Senapati (23.00\%), Kiyamgai of Imphal East (19.50\%), Kangpokpi of Senapati (18.10\%), Khangabok of Thoubal (18.10\%), Iroisemba of Imphal West (12.50\%), Keinou of Bishnupur (11.20\%) and lowest was found at Toubul of Bishnupur (10.70\%) .The Fusarium wilt of pea caused by Fusarium oxysporum f.sp. pisi was found well distributed at different pea growing districts of Manipur. The results showed variation on the natural incidence of Fusarium wilt of pea and it ranged from 10.70 to $39.50 \%$. The present finding are similar with the finding of Maheshwari et al. (1983) who reported that the assessment of losses due to wilt complex 
Table 2: Incidence of Fusarium wilt of pea caused by Fusarium oxysporum f. sp. pisi in different districts of Manipur

\begin{tabular}{lllccc}
\hline $\begin{array}{l}\text { SI. Districts } \\
\text { No. }\end{array}$ & Location & \multicolumn{2}{c}{$\begin{array}{c}\text { Disease in- } \\
\text { cidence (\%) }\end{array}$} & $\begin{array}{c}\text { Average } \\
\text { disease }\end{array}$ \\
\cline { 3 - 5 } & & & 2014 & 2015 & $\begin{array}{c}\text { (\%) } \\
\text { incidence }\end{array}$ \\
\hline 1. & Imphal East & Thongju & 29.2 & 32.5 & 30.8 \\
& & Kiyamgai & 20.0 & 22.0 & 21.0 \\
2. & Imphal west & Iroisemba & 17.5 & 20.1 & 12.5 \\
& & Nambol & 21.0 & 18.0 & 19.5 \\
3. & Thoubal & Lilong & 26.3 & 27.5 & 26.9 \\
& & Khangabok & 18.7 & 16.9 & 17.8 \\
4. & Bisnupur & Toubul & 10.4 & 11.1 & 10.7 \\
& & Keinou & 11.5 & 10.8 & 11.2 \\
5. & Ukhrul & Litan & 39.5 & 40.0 & 39.5 \\
& & Kashung & 32.7 & 33.9 & 33.3 \\
& & khullen & & & \\
6. & Senapati & Kangpokpi & 19.8 & 16.4 & 18.1 \\
& & Mao Maram & 21.7 & 24.3 & 23 \\
7. & Tamenglong & Awangkhul & 24.9 & 27.1 & 26 \\
& & Kahulong & 25.2 & 26.1 & 25.6 \\
\hline
\end{tabular}

caused by Fusarium solani f.sp pisi and F.oxysporum f.sp.pisi was found to be 13.9 to $95 \%$ in Hoshiarpur district of Punjab. Again Sharma et al., (1989) who conducted a survey during 1981-83 reported that Fusarium wilt and wilt incidence was recorded up to $37.39 \%$ at 50 villages of 6 district in Madhya Pradesh. The difference in the disease incidence may be due to difference in local situation like cropping pattern, cultural practices, variety of seed used and microclimatic condition.

3.2. Identification of the causal pathogen and pathogenecity test of the isolated fungus

Diseased samples were collected from the different pea growing districts of Manipur during the survey and isolation of the causal pathogen was carried out in the laboratory on potato dextrose agar (PDA). With repeated isolations, Fusarium oxysporum was consistently found to be associated with infected plants of pea. Fusarium oxysporum isolated from wilted pea plant were identified microscopically by their morpholocally characteristics such as abundance of micro and fewer macro conidia and white to creamy white colour culture on PDA medium. Microconidia were cylindrical, slightly curved, hyaline and were produced on short unbranched monophialides. Pathogenity test of $F$. oxysporum was carried out as described in materials and methods. The symptoms produced were similar to the symptoms shown in the infected plants taken from the farmer's field and hence the causal pathogen was proved as $F$. oxysporum.
The fungus F.oxysporum was consistently isolated from the diseased samples of wilt of pea. The isolated fungus was purified and identified as $F$. oxysporum on the basis of morphological characteristics and taxonomic keys available in the literature (Haware and Nene, 1982; Haq and Jamil, 1995). The fungus isolated from the diseased samples was found to be pathogenic. When artificially inoculated in soil and pea was grown it could cause wilt disease. On re-isolation the same pathogen was found showing its pathogenicity of the pathogen.

\subsection{Collection of soil samples from Rhizosphere of pea}

Soil collected from the rhizosphere of different pea growing district of Manipur during 2014 for the presence of Trichoderma spp.

\subsection{Isolation and identification of Trichoderma spp.}

Soil collected from the rhizosphere of different pea growing districts of Manipur were tested and Trichoderma isolates which were morphologically identified. Four native Trichoderma isolates viz., TIE-1, TBI-2, TIW-1 and TSE-1 were isolated from different rhizospheres of healthy pea plants grown in different districts of Manipur. Similarly (Harman, 2000; Smith, 1995). Reported Trichoderma genus was often the predominant component of the mycoflora in soils of various ecosystems, such as agricultural fields, prairie, forest, salt marshes and deserts, in all climatic zones. Indo-Burma region is also considered a hot spot region of biodiversity and Manipur is likely to harbor useful Trichoderma isolates.

\subsection{Pot experiment}

\subsubsection{Germination percentage}

The data on germination percentage were recorded in Table 3. showed that the germination percentage in isolate TIE-1 of seed, soil and combination of seed and soil treatment were $60 \%, 66.60 \%$ and $80.20 \%$ respectively, in isolate TBI-2 seed, soil, seed plus soil treatment were $66.6 \%, 54.30 \%$ and $72.6 \%$ respectively, in isolates TIW- 1 , seed, soil, seed plus soil treatment were $86.60 \%, 60.00 \%$ and $70.20 \%$ respectively, in isolate TSE-1 seed, soil and seed plus soil treatment were $60.00 \%$ and $72.0 \%$. The percentage recorded in seed, soil and seed plus soil treatment were $53.60 \%, 60.00 \%$ and $65.00 \%$ respectively. However in untreated control the germination percentage was found less which was only $53.0 \%$. Germination percentage of commercial Trichoderma viride in seed, soil and seed plus treatment were $66.60 \%, 80.00 \%$ and $68,60 \%$ respectively, in commercial Trichoderma hamatum the germination percentage recorded in seed, soil and seed plus soil treatment were $53.60 \%, 60.00 \%$ and $65.00 \%$ respectively. However in untreated control the germination percentage was found less which was only $53.00 \%$.

\subsubsection{Disease incidence}

The data on disease incidence of Fusarium wilt disease was recorded and presented on table 3 . Results showed that the disease incidence in 30 DAS, 60 DAS and 90 DAS of seed, 
Table 3: Effect of native Trichodema isolates on germination percentage and disease incidents of pea under pot condition

\begin{tabular}{|c|c|c|c|c|c|c|}
\hline \multirow[t]{2}{*}{$\begin{array}{l}\text { SI. } \\
\text { No. }\end{array}$} & \multirow[t]{2}{*}{$\begin{array}{l}\text { Trichoder- } \\
\text { ma spp. }\end{array}$} & \multirow[t]{2}{*}{$\begin{array}{l}\text { Treat- } \\
\text { ments }\end{array}$} & \multirow[t]{2}{*}{$\begin{array}{l}\text { Germination } \\
\text { percentage }\end{array}$} & \multicolumn{3}{|c|}{$\begin{array}{c}\text { Disease } \\
\text { incidents }\end{array}$} \\
\hline & & & & 30 & 60 & 90 \\
\hline \multirow[t]{3}{*}{1.} & TIE-1 & Seed & $60.00(7.78)$ & $\mathrm{Nil}$ & 13.3 & 26.6 \\
\hline & & Soil & $66.60(8.19)$ & Nil & 0 & 15.4 \\
\hline & & $\begin{array}{l}\text { Seed+ } \\
\text { soil }\end{array}$ & $80.20(8.98)$ & Nil & 0 & 10.66 \\
\hline \multirow[t]{3}{*}{2.} & TBI-2 & Seed & $54.30(7.40)$ & $\mathrm{Nil}$ & 13.3 & 26.6 \\
\hline & & Soil & $66.60(8.19)$ & Nil & 0 & 15.9 \\
\hline & & $\begin{array}{l}\text { Seedt } \\
\text { soil }\end{array}$ & $72.60(8.55)$ & Nil & 0 & 13.33 \\
\hline \multirow[t]{3}{*}{3.} & TIW-1 & Seed & $60.00(7.78)$ & Nil & 6.6 & 26.6 \\
\hline & & Soil & $70.20(8.40)$ & Nil & 6.6 & 20 \\
\hline & & $\begin{array}{l}\text { Seed+ } \\
\text { soil }\end{array}$ & $86.60(9.33)$ & Nil & 0 & 18.2 \\
\hline \multirow[t]{3}{*}{4.} & TSE-1 & Seed & $60.00(7.78)$ & Nil & 6.6 & 26.6 \\
\hline & & Soil & $60.00(7.78)$ & $\mathrm{Nil}$ & 6.6 & 26.6 \\
\hline & & $\begin{array}{l}\text { Seed+ } \\
\text { soil }\end{array}$ & $72.10(8.52)$ & Nil & 2.5 & 17.3 \\
\hline \multirow[t]{3}{*}{5.} & T. viride & Seed & $66.60(8.19)$ & Nil & 13.3 & 20 \\
\hline & & Soil & $68.60(8.31)$ & Nil & 6.6 & 33.3 \\
\hline & & $\begin{array}{l}\text { Seedt+ } \\
\text { soil }\end{array}$ & $80.00(8.97)$ & Nil & 0 & 18 \\
\hline \multirow[t]{3}{*}{6.} & $\begin{array}{l}\text { T. hama- } \\
\text { tum }\end{array}$ & Seed & $53.60(7.36)$ & Nil & 20 & 26.6 \\
\hline & & Soil & $60.00(7.78$ & Nil & 13.3 & 40 \\
\hline & & $\begin{array}{l}\text { Seed+ } \\
\text { Soil }\end{array}$ & $65.00(8.09)$ & Nil & 0 & 17.5 \\
\hline 7. & Control & & $53.30(7.33)$ & Nil & 33.3 & 46.6 \\
\hline \multicolumn{2}{|c|}{ SEd \pm} & & 0.05 & & 0.33 & 0.61 \\
\hline \multicolumn{2}{|c|}{$C D(p=0.05)$} & & 0.11 & & 0.67 & 1.23 \\
\hline
\end{tabular}

Values in parentheses are Square Root Transformed values; TIE-1: Trichoderma Imphal East-1; TBI-2: Trichoderma Bishnupur-2; TIW: Trichoderma Imphal west-1; TSE-1: Trichoderma Senapati-1

soil and seed plus soil treatment of the entire four native Trichoderma isolates and two commercial Trichoderma. In 30DAS, the disease incidences of all isolates were found nil. In 60 DAS, the disease incidence of isolates TIE-1 and TBI-2 of seed, soil, seed plus soil treatment were $0.00 \%, 13.30 \%$ and $0.00 \%$ respectively, in isolate TIW- 2 of seed, soil and seed plus soil treatment were $6.60 \%, 0.00 \%$ and $2.50 \%$ and in isolate TSE-1 of seed, soil and seed plus soil treatment were $6.60 \%, 6.60 \%$ and $2.50 \%$ respectively. In commercial
Trichoderma viride of seed, soil and seed plus soil were $6.60 \%, 13.30 \%$ and $0 \%$ respectively, in Trichoderma hamatum of seed, soil and seed plus soil were $13.30 \%, 20.00 \%$ and $0.00 \%$ respectively. However in untreated control disease incidence was $33.30 \%$. In 90 DAS, the disease incidence of isolate TIE-1 of seed, soil and in combination of seed and soil treatment were $10.66 \%, 26.60 \%$ and $15.40 \%$ respectively, in isolate TBI-2 of seed, soil and seed plus soil treatment were $13.33 \%, 26.60 \%$ and $15.90 \%$ respectively, in isolate TIW-1 of seed, soil and seed plus treatment were $20.00 \%, 26.60 \%$ and $18.20 \%$ respectively and in isolate TSE-1 of seed, soil and in combination of seed and soil treatment were $26.66 \%$, $26.60 \%$ and $17.30 \%$ respectively. In commercial Trichoderma viride treatment in seed, soil and seed plus soil were $20.00 \%, 33.30 \%$ and $18.00 \%$ respectively and in commercial Trichoderma hamatum treatment in seed, soil and seed plus soil were $26.60 \%, 40.00 \%$ and $17.50 \%$ respectively whereas in control without treated the disease incidence was $46.60 \%$.

\subsubsection{Plant height}

Data on the effect of four native Trichoderma isolates and two commercial Trichoderma on the height of pea plants at 3060 and 90 days after sowing of different treatment seed, soil and seed plus soil are presented on Table 4. Results showed that among the different treatments in TIE-1, TBI2, TIW-1, TSE-1, Trichoderma viride and T. hamatum, seed plus soil treatment was found to be the best. In isolate TIE1 treated pot plant height of seed, soil and seed plus soil treatment ranged from $14.32 \mathrm{~cm}$ to $18.99 \mathrm{~cm}, 39.50 \mathrm{~cm}$ to $56.88 \mathrm{~cm}$ and $56.88 \mathrm{~cm}$ to $62.67 \mathrm{~cm}$ respectively; in TBI2 it was ranged from $13.90 \mathrm{~cm}$ to $18.47 \mathrm{~cm}, 34.90 \mathrm{~cm}$ to $42.88 \mathrm{~cm}$ and $60.78 \mathrm{~cm}$ to $70.28 \mathrm{~cm}$, in TIW-1 it was ranged from $13.24 \mathrm{~cm}$ to $17.90 \mathrm{~cm}, 34.50 \mathrm{~cm}$ to $39.99 \mathrm{~cm}$ and 60.56 $\mathrm{cm}$ to $69.50 \mathrm{~cm}$ respectively and in TSE-1, it was ranged from $13.53 \mathrm{~cm}$ to $17.60 \mathrm{~cm}, 33.12 \mathrm{~cm}$ to $40.23 \mathrm{~cm}$ and $61.10 \mathrm{~cm}$ to $69.50 \mathrm{~cm}$ respectively. The plant height of commercial T.viride treatment of seed, soil and seed plus soil were also ranged from $13.54 \mathrm{~cm}$ to $17.12 \mathrm{~cm}, 34.10 \mathrm{~cm}$ to $39.89 \mathrm{~cm}$ and $61.55 \mathrm{~cm}$ to $65.89 \mathrm{~cm}$ respectively and in commercial $T$. hamatum, it was ranged from $13.30 \mathrm{~cm}$ to $17.30 \mathrm{~cm}, 34.70$ $\mathrm{cm}$ to $41.67 \mathrm{~cm}$ and $59.90 \mathrm{~cm}$ to $67.66 \mathrm{~cm}$ respectively. However in untreated control pots, the plant height ranged from $9.78 \mathrm{~cm}$ to $49.89 \mathrm{~cm}$ at $30-90$ days after planting.

\subsubsection{Plant canopy}

Plant canopy of each treatment were measured at 30.60 and 90 days after sowing from East-West and North-South direction and result were presented on table 4 . Result showed that the canopy area of the pea plant was found to be higher in seed + soil treatment of all the four native Trichoderma isolates and two commercial Trichoderma viz., T. viride and T. hamatum. Canopy of plants in isolate TIE-1 of seed, soil and seed+soil treatments were ranges from $118.90-120.79 \mathrm{~cm}^{2}$, $916.24-1009.08 \mathrm{~cm}^{2}$ and $2014.2085 .01 \mathrm{~cm}^{2}$ respectively. In isolate TBI-2 it was ranges from $117.99-139.89 \mathrm{~cm}^{2}, 909.17-$ $1003.77 \mathrm{~cm}^{2}$ and $1998.45-2078.783 \mathrm{~cm}^{2}$ respectively, in isolate 


\begin{tabular}{|c|c|c|c|c|c|c|c|c|c|c|}
\hline \multirow{2}{*}{$\begin{array}{l}\text { Sl. } \\
\text { No. }\end{array}$} & \multirow{2}{*}{$\begin{array}{l}\text { Trichderma } \\
\text { spp. }\end{array}$} & \multirow[t]{2}{*}{ Treatments } & \multicolumn{3}{|c|}{ Plant height $(\mathrm{cm})$} & \multicolumn{3}{|c|}{ Plant canopy $\left(\mathrm{cm}^{2}\right)$} & \multirow{2}{*}{$\begin{array}{l}\text { No. of pods } \\
\text { plant }^{-1}\end{array}$} & \multirow{2}{*}{$\begin{array}{c}\text { Yield } \\
\text { (g) }\end{array}$} \\
\hline & & & 30 DAS & 60 DAS & 90 DAS & 30 DAS & 60 DAS & 90 DAS & & \\
\hline \multirow[t]{3}{*}{1} & TIE-1 & Seed & 14.32 & 39.5 & 62.54 & 118.9 & 999.98 & 2014.06 & 3.9 & 6 \\
\hline & & Soil & 16.66 & 41.2 & 62.67 & 119.9 & 916.24 & 2025.09 & 4.2 & 6.2 \\
\hline & & Seed+soil & 18.99 & 46.42 & 56.8 & 120.79 & 1009.08 & 2085.03 & 5.34 & 6.91 \\
\hline \multirow[t]{3}{*}{2} & TBI-2 & Seed & 13.9 & 34.9 & 60.78 & 117.99 & 976.1 & 2010.18 & 3.78 & 5.89 \\
\hline & & Soil & 15.89 & 41 & 61.2 & 120.45 & 909.17 & 1998.45 & 4 & 6.11 \\
\hline & & Seed+soil & 18.47 & 42.88 & 70.28 & 139.89 & 1003.77 & 2078.78 & 5.11 & 6.67 \\
\hline \multirow[t]{3}{*}{3} & TIW-1 & Seed & 13.24 & 34.5 & 60.56 & 117.03 & 879.99 & 2003.1 & 3.47 & 5.56 \\
\hline & & Soil & 15.47 & 39.66 & 61.12 & 117.99 & 900.1 & 1990.24 & 3.88 & 5.99 \\
\hline & & Seed+soil & 17.9 & 39.99 & 69.5 & 136.37 & 1001.58 & 2023.32 & 4.99 & 6.46 \\
\hline \multirow[t]{3}{*}{4} & TSE-1 & Seed & 13.53 & 33.12 & 61.1 & 120 & 895 & 1899.41 & 3.4 & 5.59 \\
\hline & & Soil & 15.5 & 40.11 & 62.45 & 120.35 & 920.01 & 1890.22 & 3.5 & 5.79 \\
\hline & & Seed+soil & 17.6 & 40.23 & 69.1 & 136 & 1000.98 & 2022 & 4.71 & 6.34 \\
\hline \multirow[t]{3}{*}{5} & T. viride & Seed & 13.54 & 34.1 & 61.55 & 121.01 & 917.47 & 1990 & 3.56 & 5.77 \\
\hline & & Soil & 15.68 & 39.9 & 62.11 & 115.78 & 915 & 1799.89 & 3.45 & 5.8 \\
\hline & & Seed+soil & 17.12 & 39.89 & 65.89 & 134.26 & 1006.05 & 2035.2 & 4.9 & 6.78 \\
\hline \multirow[t]{3}{*}{6} & T. hamatum & Seed & 13.3 & 34.7 & 59.9 & 120.17 & 921 & 1999.98 & 3.6 & 5.68 \\
\hline & & Soil & 15.29 & 45.9 & 61.24 & 113.89 & 900.11 & 2100.59 & 3.78 & 5.85 \\
\hline & & Seed+soil & 17.3 & 41.67 & 67.66 & 138.56 & 1000.78 & 2021.01 & 4.89 & 6.86 \\
\hline 7 & Control & & 9.78 & 25.81 & 49.81 & 90.93 & 800.04 & 139.993 & 3.36 & 5.5 \\
\hline \multicolumn{2}{|c|}{ SEd \pm} & & 0.31 & 0.82 & 0.52 & 1.26 & 16.73 & 26.71 & 0.09 & 0.13 \\
\hline \multicolumn{2}{|c|}{$\mathrm{CD}(p=0.05)$} & & 0.62 & 1.66 & 1.05 & 2.55 & 33.92 & 54.18 & 0.18 & 0.26 \\
\hline
\end{tabular}

TIW-1 it was ranged from $117.03-136.37 \mathrm{~cm}^{2}, 879.99-1001.58$ $\mathrm{cm}^{2}$ and $1990.24-2023.32 \mathrm{~cm}^{2}$ respectively and in isolate TSE-1 it was ranged from $120.00-136.00 \mathrm{~cm}^{2}, 895.00-1000.98$ $\mathrm{cm}^{2}$ and $1890.22-2022.01 \mathrm{~cm}^{2}$ respectively. In commercial Trichoderma viride it was ranged from $115.78-134.26 \mathrm{~cm}^{2}$, $915.00-1006.05 \mathrm{~cm}^{2}$ and $1799.89-2035.20 \mathrm{~cm}$ whereas in $T$. hamatum it was ranged from $113.89-138.56 \mathrm{~cm}^{2}, 900.11-$ $1000.78 \mathrm{~cm}^{2}$ and $1999.98-2021.01 \mathrm{~cm}^{2}$ respectively. In control pots, plant canopy were ranges from $90.93-139.99 \mathrm{~cm}^{2}$.

\subsubsection{No of pods plant ${ }^{-1}$}

Effect of native four Trichoderma isolates and commercial Trihoderma viz., T.viride and T. hamatum on the yield parameters of pea are presented on Table 4. Among the different treatments seed+soil was found to be better than soil and seed treatment. The number of pods per plant in seed+soil treatment in isolate TIE-1 was 5.34 followed by TBI-2 (5.11), TIW-1 (4.99), T. viride (4.90), T. hamatum (4.89) and TSE-1 (4.71). In soil treated treatment isolate TIE-1 was found best in which the number of pods per plant was 4.20 followed by TBI-2 (4.00), TIW-1 (3.88), T. hamatum (3.78), TSE-1 (3.50) and T.viride (3.45) respectively. Number of pods plant $^{-1}$ in seed treated with isolate TIE-1 was 3.90 followed by TBI-2 (3.78), T. hamatum (3.600. T. viride (3.56), TIW-1 (3.47) and TSE-1 (3.40). However in untreated pot the number of pods per plant was found lowest which were only 3.36 .

\subsubsection{Yield}

Effect of four native Trichoderma isolates and two commercial Trichoderma i.e T.viride and T. hamatum on the yield of pea under pot trial are presented on table 4. Yield was found to be high in seed+soil treatment in all. Isolate TIE-1 was found to be highest which was $\left(4.84 \mathrm{~g} \mathrm{pot}^{-1}\right)$ followed by $T$. hamatum (4.69 $\left.\mathrm{g} \mathrm{pot}^{-1}\right), \mathrm{TBI}-2\left(4.67 \mathrm{~g} \mathrm{pot}^{-1}\right)$, T.viride (4.60 g pot $\left.^{-1}\right)$, TIW-1 (4.54 $\left.\mathrm{g} \mathrm{pot}^{-1}\right)$ and TSE-1 (4.32 $\left.\mathrm{g} \mathrm{pot}^{-1}\right)$. Yield of pods pot ${ }^{-1}$ in soil treated with isolate TIE-1 was found best which was $4.42 \mathrm{~g} \mathrm{pot}^{-1}$ followed by TBI-2 (4.34 $\left.\mathrm{g} \mathrm{pot}^{-1}\right)$, TIW1and T. viride (4.10 $\left.\mathrm{g} \mathrm{pot}^{-1}\right)$ and TSE-1 and T. hamatum (4.09 $\left.\mathrm{g} \mathrm{pot}^{-1}\right)$ while yield of pods pot ${ }^{-1}$ in seed treated with isolate TIE-1 showed best $\left(4.26 \mathrm{~g} \mathrm{pot}^{-1}\right)$ followed by TBI-2 (4.11 g pot $\left.^{-1}\right), T$. hamatum $\left(4.09 \mathrm{~g} \mathrm{pot}^{-1}\right), T$. viride $\left(4.08 \mathrm{~g} \mathrm{pot}^{-1}\right)$, TSE$1\left(4.06 \mathrm{~g} \mathrm{pot}^{-1}\right)$ and TIW-1 (4.00 $\left.\mathrm{g} \mathrm{pot}^{-1}\right)$. Lowest yield was found obtained in control which was only $3.42 \mathrm{~g} \mathrm{pot}^{-1}$. In pot trial four native Trichoderma isolates viz., TIE-1. TBI- 
2, TIW-1 and TSE-2 along with two commercial Trichoderma spp. viz., $T$. viride and $T$. hamatum were evaluated against Fusarium oxysporum f. sp. pisi showed significant reduction in disease incidences, increasing germination per cent, growth and yield of pea as compared to control under pot condition. These findings are in agreement with those of several workers (Chet, 1997). There are several reports of biocontrol of pathogens in in vivo conditions against soil borne diseases (Smith et al., 1990; Mishra and Sinha, 2000; Singh, 2003; Singh et al., 2007) Moreover; recent studies have indicated that these fungi also induced localized or systemic resistance systems in plants (Yedidia et al., 1999). Prasad et al. (2002) reported that biopriming with Trichoderma resulted into increased germination (\%), root and shoot length of red gram under field conditions. Effective biological control agents have been developed for control of seed and seedling pathogens such as Pythium spp., R. solani, S. rolfsii, M. phaseolina and Fusarium spp. several researchers have reported the biological seed treatments for protection of seed and control of pathogens causing seedling diseases (Harman, 1991; Bennett et al., 1992; Chet and Inbar, 1994).

\section{Conclusion}

The treatment of native Trichoderma isolates and commercial Trichoderma showed reduction in disease incidence of Fusarium wilt of pea and also increased in germination \%, plant height, plant canopy and yield in comparison with untreated control. The result also revealed that among the different treatments seed + soil treatment was found better than seed and soil treatment alone. Thus it can be concluded that native Trichoderma isolates can be used as effective biocontrol agent to reduce wilt disease and to develop ecofriendly strategy for the management of Fusarium wilt of pea.

\section{References}

Anonymous, 2015. Annual Report (2014-15) on Promotion of Pulses in NEH region. ICAR-Indian Institute of Pulses Research, Kanpur, Uttar Pradesh 208024 (India), 39.

Anonymous, 2013. State of Indian Agriculture 2012-2013. Printed and published by Directorate of Economics and Statistics, Ministry of Agriculture, Government of India, New Delhi.

Bennett, M.A., Fritz, V.A., Callan, N.W., 1992. Impact of seed treatments on crop stand establishment. HortTechnology, 345-349.

Benitez, T., 2004. Biocontrol mechanisms of Trichoderma strains. International microbiology 7, 249-260.

Chet, I., Inbar, J., 1994. Biological control of fungal pathogens. Applied Biochemistry Biotechnology 48, 37-43.

Chet, I., Inbar, J., Hadar, I., 1997. Fungal antagonists and mycoparasites. Environmental and Microbial Relationships, 165-184.
Chet, I., Chernin, L., 2002. Microbial enzymes in the biocontrol of plant pathogens and pests. In Enzymes in the environment, Burns, R.G., Dick, R.P. (Eds.), (New York: Marcel Dekker, Inc.), 171-226.

Chupp, C., Sherf, A.F., 1960. Vegetable disease and their control. The Ronald Press Company, New York, 668

Haglund, W.A., Kraft, J.M., 2001. Fusarium wilt. In: Kraft, J.M., Pfleger F.L. (Eds.), Compendium of Pea Diseases and Pests. APS Press, St. Paul, 13-14.

Harman, G.E., 2000. Trichoderma spp. including T. harzianum, $T$. viride, $T$. koningii, $T$. hamatum and other spp. Deuteromycetes, Monilialea (asexual classification system). Biol control. A guide to Natural Enemies in North America.

Harman, G.E., Jin, X., Stasz, T.E., Peruzzotti, G., Leopold, A.C., Taylor, A.G., 1991. Production of conidial biomass of Trichoderma harzianum for biological control. Biological control 1, 23-28.

Harman, G.E., 2004. Trichoderma species opportunistic, avirulent plantsymbionts. Nature Reviews Microbiology 2, 43-56.

Harman, G.E., 2004b. Trichoderma species opportunistic, avirulent plant symbionts. Nature Reviews Microbiology 2, 43-56.

Haware, M.P., Nene, Y.L., 1982. Symptomless carriers of chickpea Fusarium wilt. Plant Disease 66, 250-251.

Haq Jamil, F.F., 1995. Comparison of vascular discoloration and growth of Fusarium oxysporum in various segments of chickpea grown in wilt sick plot in Faisalabad, Pakistan. International Chickpea and Pigeonpea News Letter 2, 30-32.

Howell, R.C., 2003. Mechanisms employed by Trichoderma species in the biological control of plant diseases, the history and evolution of current concepts. Plant Disease 87, 4-10.

Infantino, A., Kharrat, M., Riccioni, L., Coyne, C.J., Kevin, E., Phee, M.C., Grunwald, N.J., 2006. Screening techniques and sources of resistance to root diseases in cool season food legumes. Euphytica, 147, 201-221.

Kraft , J.M., 1995. Fusarium wilt of peas (A review). Agronomie 14, 561-567.

Kraft, J.M., Peleger, F.L., 2001. Compendium of Pea Diseases and Pests. $2^{\text {nd }} \mathrm{Ed}$. The American Phytopathological Society, St. Paul.

Kubicek, C.P., 2001. Trichoderma: from genes to biocontrol. Journal of Plant Pathology 83, 11-23.

Maheshwari, S.K., Jhooty, J.S., Gupta, J.S., 1983. Survey of wilt and root rot of complex of pea in Northern India and the assessment of losses. Agricultural Science Digest, India $3(3 / 4), 139-141$.

Mishra, D.S., Sinha, A.P., 2000. Plant growth promoting activity of some fungal and bacteria agents on rice seed germination and seedling growth. Tropical Agriculture 77, 188-191. 
Pan, S., Bhagat, S., 2007. Antagonistic potential of Trichoderma species and Gliocladium species from West Bengal. Journal of Mycology and Pathology 37, 235-239.

Phal, R., Choudhury, B., 1983. Fusarium wilt of garden pea: race situation. Journal of Agricultural Science 53(9), 863-865.

Prasad, R.D., Rangeshwaran, R., Anuroop, C.P., Rashni, H.J., 2002. Biological control of wilt and root rot of chickpea under field conditions. Animals of Plant Protection Sciences 10(1), 72-75.

Saha, D.K., Pan, S., 1997. Qualitative evaluation of some specific media of Trichoderma and Gliocladium and their possible modifications. Journal of Mycopathological Research 34, 7-13.

Sardana, S., Mahajan, R.K., Gautam, N.K., Ram, B., 2007. Genetic variability in pea (Pisum sativum L.) germplasm for utilization. SABRAO Journal of Breeding and Genetics, 39(1), 31-41.

Sharma, B.L., Parasar, R.D., Sudh, B., 1989. Studies on survey of Fusarium wilt of pea in Nothern region of Madhya Pradesh. Legume Research 12(3), 151-152.

Smartt, J., 1990. Grain Legumes: Evolution and Genetic resources. Cambridge University Press, Cambridge, UK.

Smith,V.L., Wilcox, W.F., Harman, G.E., 1990. Potential for biological control of Phytophthora root and crown rot of apple by Trichoderma and Gliocladium spp. Phytopathology 80, 880-885.
Smith, W.H., 1995. Forest occurrence of Trichoderma species. Ecotoxicology and Environmental Safety 32, 179-183.

Singh, M.M.S., 2003. Shelf life of different formulations of mutant and parent strain of Trichoderma harzianum at variable temperatures. Plant Disease 18(2), 316-320.

Singh, M., Singh, P.N., 2007. Pesticidal tolerance to fungal bio-control agents. Annals of Plant Protection Sciences 15(2), 418-420.

Steyaert., 2003. Genetic basis of mycoparasitism: a mechanism of biological control by species of Trichoderma. New Zealand Journalof Crop and Horticultural Science 31, 281-291.

Sukapure, R.S., Bhide, V.P., Patel, M.K., 1957. Fusarium wilt of garden peas (Pisum sativum L.) in Bombay state. Indian Phytopathology 10, 11-17.

Weideman, H., Wehner, F.C., 1993. Green house evaluation of Trichoderma harzianum and Fusarium oxysporum for biological control of citrus root rot in soils naturally and artificially infected with Phytophthora nicotianae. Phytophylactica 25, 101-105.

Yedidia, I., Benhamou, N., Chet, I., 1999. Induction of defense responses in cucumber plants (Cucumis sativus L.) by the biocontrol agent Trichoderma harzianum. Applied and Environmental Microbiology 65, 1061-1070.

Yedidia, I., Chet, I., 2001. Effect of Trichoderma harzianum on microelement concentrations and increased growth of cucumber plants. Plant Soil 235, 235-242. 